


\title{
THE HYPO-OSMOTIC SWELLING TEST IN FRESH GARUT RAM SPERMATOZOA
}

\author{
W. M. M. Nalley ${ }^{1}$ and R. I. Arifiantini ${ }^{2}$ \\ ${ }^{1}$ Faculty of Animal Science, Nusa Cendana University, \\ Jln. Adi Sucipto Penfui Kupang, East Nusa Tenggara-Indonesia \\ ${ }^{2}$ Faculty of Veterinary Medicine, Bogor Agricultural University, \\ Darmaga Campus, Bogor 16680 - Indonesia \\ Corresponding E-mail: nalleywm@yahoo.co.id
}

Received October 15, 2013; Accepted November 27, 2013

\begin{abstract}
ABSTRAK
Penelitian ini bertujuan untuk menentukan waktu optimum untuk pengujian membran plasma yang utuh (MPU) pada sperma domba garut setelah inkubasi pada larutan hypo-osmotic. Sebanyak 24 ejakulat dari 8 ekor semen domba garut yang telah dewasa kelamin dikoleksi menggunakan vagina buatan. Semen dievaluasi secara makroskopis selanjutnya dilakukan pengujian MPU dengan mengambil $10 \mu \mathrm{L}$ semen segar dan dimasukkan ke dalam $2 \mathrm{~mL}$ larutan hypo-osmotic kemudian diinkubasi pada suhu $37^{\circ} \mathrm{C}$ selama 1 jam. Sample dievaluasi setiap 15 menit dengan menghitung 200 sperma yang bereaksi (coil) dan yang tidak bereaksi dari lima lapang pandang. Hasil penelitian menunjukkan waktu optimal pengujian MPU menggunakan larutan hypo-osmotic adalah 30 menit dan tidak ada perbedaan antar 8 domba jantan yang digunakan
\end{abstract}

Kata Kunci : Keutuhan membran plasma, Semen domba garut, HOS test

\begin{abstract}
The study was aimed to determine the optimal time to evaluate the maximum numbers of swollen sperm after expose to hypo-osmotic solution for testing membrane integrity in fresh garut ram semen. A total of 24 ejaculate samples from eight sexually mature garut ram were collected using artificial vagina. After macroscopic evaluation, $10 \mu \mathrm{L}$ undiluted semen was gently mixed in each of the $2 \mathrm{~mL}$ hypoosmotic solution and incubated at $37^{\circ} \mathrm{C}$ for 1 hour. Two hundred of coil and non-coiled sperm were observed from five different fields every 15 minutes. Results demonstrated that the maximum percentage of coiling sperm positive to HOS test was at 30 minutes and no differences among 8 garut rams used.
\end{abstract}

Keywords: hypo-osmotic swelling test, garut rams semen, membrane integrity

\section{INTRODUCTION}

The plasma membrane surrounds the entire sperm cell holding together its organelles and intracellular components. Viable sperm are defined as cells that possess an intact plasma membrane. Membrane integrity is a fundamental requisite for sperm viability and for the success of fertilization. In recent years more attention has been dedicated to study this area. Two tests have been available to evaluate membrane integrity supravital stains and the hypo-osmotic swelling (HOS) test.

The hypo-osmotic swelling test has proved to be a good tool for evaluating the membrane integrity of sperm of various domestic animals including bull (Revell and Mrode, 1994; Rota et al., 2000; Brito et al., 2003; Bacinoglu et al., 2008; Padrik et al., 2012), stallion (Neild et al., 1999; Nie and Wenzel, 2001; Eshleman and Pinto, 2010), and boar (Vazquez et al., 1997; PerezLlano et al., 2001, 2003; Yeste et al., 2010), dog (Dobranić et al., 2005; Tomislav et al., 2005), buck (Fonseca et al., 2005; Leboeuf et al., 2006), deer (Nalley, 2011) and rabbit (Amorim et al., 2009). Each species of animal contains a different membrane composition (Miller et al., 2005), therefore the characteristics of membranes that affect their sensitivity include the response to hypo-osmotic solution is different. 
When sperm encounter hypo tonic environments, they react to hypoosmolality by developing bent or curled of sperm tails due to the influx of water during reestablishment of osmotic equilibrium. In the classic HOS test this property is used to characterize membrane integrity (Jeyendran et al., 1984). However, a wide range of animal cell types, including sperm, are able to maintain their volume after osmotic shock, thereby avoiding the consequences of excessive volume changes (Lang et al., 1998).

Since there were differences among sperm membrane composition,-the percentage of sperm cells response to HOS test varies highly in its degree. The present study aimed to determine the optimal time to evaluate maximum numbers of swollen/coiling sperm of fresh garut ram semen after expose to hypo-osmotic solution in for membrane integrity testing.

\section{MATERIALS AND METHODS}

\section{Semen Collection and Evaluation.}

Twenty four ejaculates ( $8 \mathrm{ram}, 3$ sample per ram) were collected using an artificial vagina, in the presence of oestrous ewe. Semen samples were placed in a water bath at $32^{\circ} \mathrm{C}$. Immediately after the collection, semen volume, $\mathrm{pH}$, color, consistency, mass activity, sperm motility, viability, sperm concentration, and percentage of sperm with morphologic abnormalities were evaluated according to standard procedures (Arifiantini, 2012).

\section{Hypoosmotic swelling test}

The hypoosmotic solution $(150 \mathrm{mOsm} / \mathrm{L})$ was prepared by dissolving $7.35 \mathrm{~g}$ sodium citrate $\left(\mathrm{Na}_{3} \mathrm{C}_{6} \mathrm{H}_{5} \mathrm{O}_{7} \cdot 2 \mathrm{H}_{2} \mathrm{O}\right)$ and $13.51 \mathrm{~g}$ fructose $7.35 \mathrm{~g}$ in $1000 \mathrm{~mL}$ of distilled water (Jeyendran et al., 1984). The solution was stored at $4^{\circ} \mathrm{C}$ till used. A volume of $10 \mu \mathrm{L}$ undiluted semen was gently mixed in each of the $2 \mathrm{~mL}$ hypo-osmotic solution and incubated at $37^{\circ} \mathrm{C}$ for 1 hour. Numbers of swollen sperm was observed every 15 minutes; a drop of incubated suspension was placed on a glass slide, covered with coverslip and examined at under a microscope at $400 \mathrm{x}$ magnification. At least 200 sperm cells on each slide were counted randomly.

\section{Statistical Analysis}

Data presented as the mean and standard deviations (SD) were analyzed by a one way analysis of variance (ANOVA). Statistical significance was set at $P<0.05$ (Santoso, 2003 )

\section{RESULTS AND DISCUSSION}

The characteristics of the ejaculates collected for analyses are reported in Table 1 mean values recorded for semen quality parameters were in agreement with standard reproductive performance of ram.

At the beginning of the incubation period $(0$ minutes) sperm not affected by hypo-osmotic solution, coiling seen only $15.29 \pm 0.88 \%$. The mean percentages of sperm with intact membrane determined by the HOST $15 \mathrm{~min}$, HOST $30 \mathrm{~min}$, HOST $45 \mathrm{~min}$ and $60 \mathrm{~min}$ were $38.16 \pm 3.89$, $69.47 \pm 2.78,42.85 \pm 4.30$ and $29.95 \pm 3.80$ respectively. Ram sperm appeared to suffer increasing coiling from 15 to 30 minutes, and reached maximum values at 30 minutes and coiling began to decrease after 45 minute (Table 2).

The sperm plasma membrane is susceptible to damage caused, for example, by osmotic stress or lipid peroxidation. The physical pressure from osmotic stress results in membrane damage, but, if the limits to membrane integrity were not exceeded, the plasma membrane will respond, behaving as an ideal osmometer. The hypoosmotic Swelling test is based on that principle. Thus, when samples are places in a hipoosmotic solution sperm with intact and functional membranes will swell and present typical coiled tails.

Table 1. Characteristic of Garut Ram Semen

\begin{tabular}{lrr}
\hline Semen Variable & \multicolumn{2}{c}{ Mean \pm SD } \\
\hline Volume $(\mathrm{mL})$ & $0.65 \pm$ & 0.32 \\
$\mathrm{pH}$ & $6.31 \pm$ & 0.29 \\
Color & milky to cream \\
Consistency & \multicolumn{2}{c}{ moderate } \\
Mass activity & $2.91 \pm 0.20$ \\
Sperm motility $(\%)$ & $72.92 \pm$ & 4.08 \\
Sperm viability $(\%)$ & $84.14 \pm$ & 5.28 \\
Sperm concentration $\left(\mathrm{x} 10^{6} / \mathrm{mL}\right)$ & $3052.08 \pm 692.11$ \\
Total sperm number $\left(\mathrm{x} 10^{6}\right)$ & $1998.86 \pm 1204.27$ \\
Sperm abnormality $(\%)$ & $6.18 \pm$ & 2.04 \\
\hline
\end{tabular}


Table 2. Percentages of Swollen Sperm (8 Ram) Subjected to HOST during One Hour Incubation Period at $37^{\circ} \mathrm{C}$

\begin{tabular}{cccccc}
\hline & \multicolumn{4}{c}{ Time (minute) } \\
\cline { 2 - 6 } & 0 & 15 & 30 & 45 & 60 \\
\hline \% Swollen Sperm & $15.29 \pm 0.88^{\mathrm{e}}$ & $38.16 \pm 3.89^{\mathrm{c}}$ & $69.47 \pm 2.78^{\mathrm{a}}$ & $42.85 \pm 4.30^{\mathrm{b}}$ & $29.95 \pm 3.80^{\mathrm{d}}$ \\
\hline
\end{tabular}

Different superscript at the same raw indicate significant differences $(\mathrm{p}<0.05)$

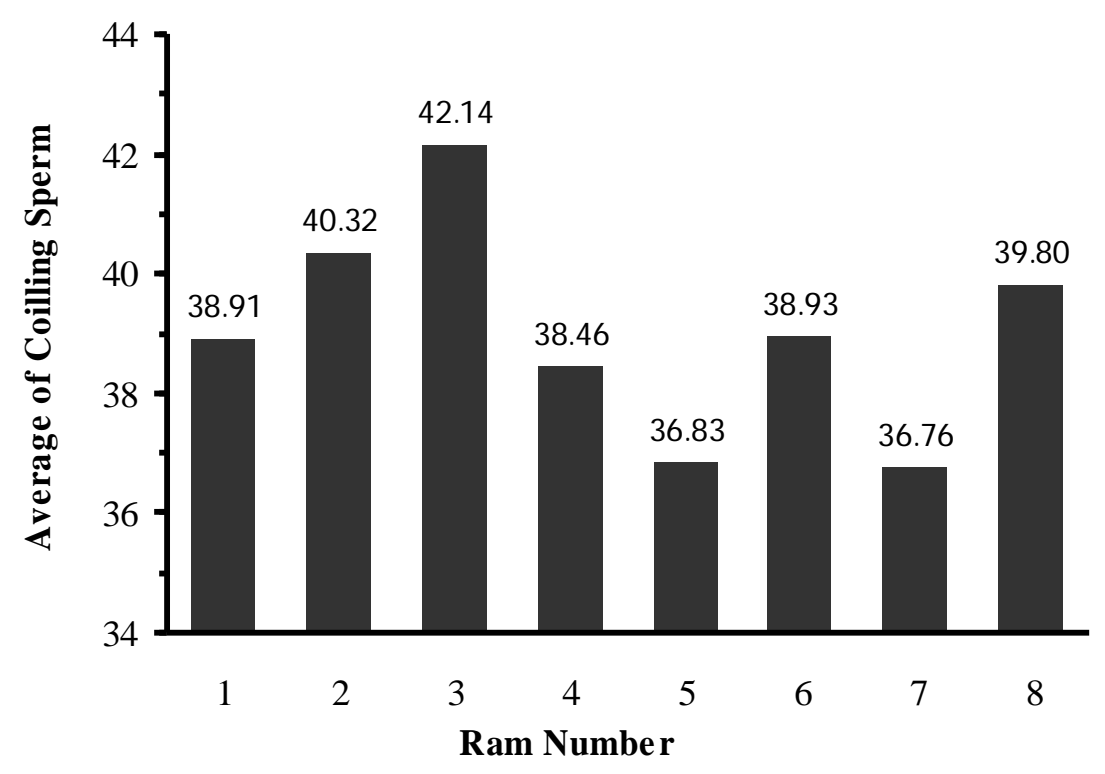

Figure 1. Average Percentage of Total Coiling in Fresh Ram Sperm (200 Cells Counted per Sample) Exposed to Hypoosmotic Solution for 60 Minutes

As with other domestic species, garut ram sperm had a similar pattern of swelling when exposed to a hypoosmotic medium. An important property of the sperm cell membrane is its ability to permit selective transport of molecules. When exposed to hypoosmotic conditions, water will enter the sperm cell in an attempt to reach osmotic equilibrium.

In reacting to the sperm, HOS test is an influx of water into the interior of cells and consequent alteration of cell volume and plasma membrane and causes a folding of the flagellum. Sperm with intact membranes absorb water and swell by increasing in volume to establish equilibrium between the fluid compartment within the sperm and the extracellular medium due the biochemically-active sperm. The hypo-osmotic swelling test is inexpensive and easy to perform, and evaluate a fundamental characteristic of the plasma membrane.

In this research no difference was observed between rams after HOS test was carried out for 60 minutes at $37^{\circ} \mathrm{C}$ (Figure 1), and the best time to evaluate HOS test for fresh semen of ram sperm was at 30 minutes incubation this finding was agreement with Vazquez et al. (1997) in boar semen 30 minutes incubation was the best compare to 5,60 or 120 minutes. The incubation time to evaluate membrane integrity with hypoosmotic solution is deferred among researchers. Amorim et al. (2009), Nur et al. (2005), Lodhi et al. (2008), Eshleman and Pinto (2010) and Padrik et al. (2012) proposed 1 hour incubated in rabbit, goat, buffalo, equine and bovine semen. Leboeuf et al. (2006) and Rota et al. (2000) only 5 minutes in goat and bovine semen. Nie and Wenzel (2001) 
reported no differences between 1 or 60 minutes in Contras Eshleman and Pinto (2010) reported 1 minutes was better than 60 minutes in stallion semen.

The incubation time seem to be not the only factor influencing the number of coiling sperm. The osmolarities of hypo-osmotic solution affect the number of coiling sperm tail. The best osmolarities solutions was $60 \mathrm{mOsm} / \mathrm{L}$ was found for rabbit sperm (Amorim et al., 2009), 125 $\mathrm{mOsm} / \mathrm{L}$ for goats semen (Fonseca et al., 2005), $100 \mathrm{mOsm} / \mathrm{L}$ for dog sperm (Tomislav et al., 2005), 25 to $100 \mathrm{mOsm} / \mathrm{L}$ for horse sperm (Neild et al., 1999) and $150 \mathrm{mOsm} / \mathrm{L}$ for cattle, human and swine's (Revell and Mrode, 1994; Jeyendran et al., 1984; Vazquez et al., 1997). According to Petrunkina et al. (2007), sperm cell able to maintain their cellular functionality in the face of such osmotic changes, sperm of several mammalian species (boar, mouse, bull, human) have been found to exhibit volume regulatory abilities, particularly regulatory volume decrease (RVD) in response to hypotonic challenge and after exposure to hypertonic conditions, the cells are able to recover their volume after initial shrinking, a process known as regulatory volume increase.

In this research the maximum coiled sperm $(69.47 \pm 2.78 \%)$ on $150 \mathrm{mOsm} / \mathrm{L}$ demonstrated at 30 minutes after incubation, and decreased after $45(42.85 \pm 4.30 \%)$ and 60 minutes (29.95 \pm $3.80 \%)$. This fenomenon explaine that the RVD of ram sperm demonstrated at that time. Since the osmolarities of hypo-osmotic solution affect the number of coiling sperm tail, this justifies the need for finding the best time to evaluate maximum response of sperm for membrane integrity when using different solution.

\section{CONCLUSION}

The best time to evaluate the garut ram sperm membrane integrity was 30 minutes after incubation.

\section{ACKNOWLEDGEMENT}

Authors gratefully acknowledge Bondan, SE., Faculty of Veterinary Medicine, Bogor Agricultural University for technical assistance.

\section{REFERENCES}

Amorima, E.A.M., C.A.A. Torres, J.K. Graham,
L.S. Amorima and L.V.L. Santos. 2009. The hypoosmotic swelling test in fresh rabbit spermatozoa. Anim. Reprod. Sci. 111:338343.

Arifiantini I. 2012. Teknik Koleksi dan Evaluasi Semen. IPB Press, Bogor

Bacinoglu, S., M, Tas, U, Cirit, O.B. Ozdas and K. Ak. 2008. The potential fertility estimation capacity of the hypoosmotic swelling test, the thermal stress test and a modified cervical mucus penetration test in the bovine. Anim. Reprod. Sci. 104:38-46

Brito, L.F.C., A.D. Barth, S. Bilodeau-Goeseels, P.L. Panich and J.P. Kastelic. 2003. Comparison of methods to evaluate the plasmalemma of bovine sperm and their relationship with in vitro fertilization rate. Theriogenology. 60:1539-1551

Dobranić, T., M. Samardzija, M. Cergolj and N. Prvanovic. 2005. Determination of membrane integrity of canine spermatozoa. Vet. Arhiv. 75(1):23-30

Eshleman, K.C. and C.R.F. Pinto. 2010. Simplifying the determination of sperm membrane integrity in stallions with the hypoosmotic swelling test. Anim. Reprod. Sci. 1215:5203-5204.

Fonseca, J.F., C.A.A. Torres, V.V. Maffili, A.M. Borges, A.D.F. Santos, M.T. Rodrigues and R.F.M. Oliveira. 2005. The hypoosmotic swelling test in fresh goat spermatozoa. Anim. Reprod. 2:139-144.

Jeyendran, R.S., H.H. Van der Ven and M. PerezPelaez. 1984. Development of an assay to assess the functional integrity of the human sperm membrane and its relationship to other semen characteristics. J. Reprod. Fertil. 70:219-228.

Lang, F., G.L. Busch, M. Ritter, H. Volkl, S. Waldegger, E. Gulbins and D. Haussinger. 1998. Functional significance of cell volume regulatory mechanisms. Physiological Reviews. 78:247-306.

Leboeuf, B., Y. Le Vern, V. Furstoss, D. Kerboeuf, P. Guillouet and M. Magistrini. 2006. Response of goat sperm to hypoosmotic steps modelled probit analysis. Anim. Reprod. Sci. 91:265-274.

Lodhi L.A., M. Zubair, Z.I. Qureshi, I. Ahmad and H. Jamil. 2008. Correlation between hypoosmotic swelling test and various conventional semen evaluation parameters in fresh Nili-Ravi Buffalo and Sahiwal cow Bull Semen. Pakistan Vet. J. 28(4):186-188. 
Miller Jr. R.R., C.L. Cornett, K.E. Waterhouse and W. Farstad. 2005. Comparative aspects of sperm membrane fatty acid composition in silver (Vulpes vulpes) and blue (Alopex lagopus) foxes, and their relationship to cell cryopreservation. Cryobiology. 51:66-75.

Nalley, W.M.M, R. Handarini, T.L. Yusuf; B. Purwantara and G. Semiadi. 2011. The effect of glycerol concentration in Tris glucose egg yolk extender on the quality of Timor Deer frozen semen. J. Indonesian Trop. Anim. Agric. 36(2):91-96

Neild, D., G. Chaves, M. F'lores, N. Mora, M. Beconi and A. Agiiero. 1999. Hypoosmotic test in Equine spermatozoa. Theriogenology. 51:721-727

Nie, G.J. and J.G.W. Wenzel. 2001. Adaptation of the hypoosmotic swelling test to assess functional integrity of stallion spermatozoal plasma membranes. Theriogenology. 55:1005-1018

Nur, Z., I. Dogan, U. Gunayand and M.K Soylu. 2005. Relationships between sperm membrane integrity and other semen quality characteristics of the semen of saanen goat bucks. Bulletin of Veterinary Institute in Pulawy. 49:183-187

Padrik, P., T. Hallap, A. Januškauskas, T. Kaart, T. Bulitko and U. Jaakma. 2012. Conventional laboratory test and flow cytometry in the prognostic testing of bull semen fertility. Vet. Med. Zoot. 60(82):52-59

Perez-Llano, B., J.L.P Lorenzo Yenes, A. Trejo and P. Garcia-Casado. 2001. Hypoosmotic swelling test for the prediction of boar sperm fertility. Theriogenology. 56:387-398

Petrunkina, A.M., D. Waberski, A.R. Gunzel-Apel and E. Topfer-Peterson. 2007. Determinants of sperm quality and fertility in domestic species. Reproduction. 134:3-17

Revell, S.G and R.A. Mrode. 1994. An osmotic resistance test for bovine semen. Anim. Reprod. Sci. 36:77-86

Rota, A., N. Penzo, L. Vincent and R. Mantovani. 2000. Hypoosmotic swelling (HOS) as a screening assay for testing In vitro fertility of bovine spermatozoa. Theriogenology. 53:1415-1420

Santoso, S. 2003. Mengatasi Berbagai Masalah Statistik dengan SPSS Versi 11.5. Jakarta. PT Elex Media Komputendo, Kelompok Gramedia. pp 291-304

Tomislav, D., S. Marko, C. Marijan and P. Nikica. 2005. Determination of membrane integrity of canine spermatozoa. Vet. Arhiv. 75(1):2330

Vazquez, J.M., A.E.A. Martinez, P. Martinez, C. Garcia-Artiga and J. Rota. 1997. Hypoosmotic swelling of boar spermatozoa compared to other methods for analysing the sperm membrane. Theriogenology 47:913922

Yeste, M., M. Briz, E. Pinart, S. Sancho, E. Bussalleu and S. Bonet. 2010. The osmotic tolerance of boar spermatozoa and its usefulness as sperm quality parameter. Anim. Reprod. Sci.119:265-274 